\title{
Introduction to "The Ebb and Flow of Federal Sector Labor-Management Relations Policies Under Four Successive Presidents"
}

\author{
Victor G. Devinatz ${ }^{1}$
}

Published online: 12 June 2020

(C) Springer Science+Business Media, LLC, part of Springer Nature 2020

In the United States, the history of federal sector labor relations goes back more than two hundred years. In the early 1800s, federal shipyard employees organized the first US public sector worker organizations although they were unable to have much influence on labor policy. The first strike of federal civilian employees occurred in 1835 at a Washington D.C. naval shipyard which concluded with a mass demonstration and a dispute with President Andrew Jackson who implemented the 10-h workday. Undoubtedly, the most significant group of US federal employees to first unionize was postal workers, specifically New York letter carriers who commenced their organizing in 1863. By 1886, the Knights of Labor had established postal worker locals in Chicago and other large US cities. In 1939, more than 70\% of US postal workers were represented by unions.

Federal employee unionization continued to expand throughout the 1960s and the 1970s when public sector union membership exploded due to public employee militancy and the passage of favorable legislation. In 1960, federal, state and municipal employee union membership increased from 903,000 (a union density of 10.8\%) to almost six million members in 1976 , representing $40.2 \%$ of public sector employees, leading to public sector union density dwarfing its private sector counterpart. According to 2020 figures, 2019 US public sector union density was more than five times higher than private sector union density $(33.6 \%$ vs. $6.2 \%)$. Thus, at the start of the twenty-first century's third decade, federal sector labormanagement relations is undoubtedly an important branch of US labor relations requiring continuing study.

In this timely, well-written and interesting "Perspectives" Section article, Dr. Marick Masters, Professor of Business at Wayne State University, Dr. Robert Albright, Chair of the Department of Management at the University of New Haven, and Dr. Raymond Gibney, Professor of Management at Penn State Harrisburg, examine federal sector labor-management relations policies under former Presidents Bill Clinton, George W. Bush, Barack Obama and the current President, Donald Trump. Specifically, these scholars investigate the abovementioned successive presidents' policies on seven dimensions, evaluating these presidents'

Victor G. Devinatz

vgdevin@ilstu.edu

1 Department of Management \& Quantitative Methods, Illinois State University, Normal, IL, USA 
programs with respect to the Federal Service Labor-Management Relations Statute. Moreover, these researchers contend that these presidents' policies regarding federal sector labormanagement relations are directly related to their positions regarding public administration, management and labor relations. Marick, Albright and Gibney discover that while major policy differences exist across the four presidents, their views correspond to their political party and ideology. One of the authors' major conclusions is that "federal sector labormanagement relations is a politically moving variable."

If any of the journal's readers are interested in responding to any essays published in the "Perspectives" Section or would like to write articles on any topics in the field of employee relations, please do not hesitate to contact me with your proposal. I welcome both practitionerbased and scholarly-based articles written from any one of a variety of theoretical perspectives. I /hope that you enjoy this article and find it most illuminating.

Victor G. Devinatz, Editor of "Perspectives" Section.

Department of Management \& Quantitative Methods.

Illinois State University.

Normal, Illinois 61790-5580.

Publisher's Note Springer Nature remains neutral with regard to jurisdictional claims in published maps and institutional affiliations. 